\title{
Editorial: Editor's Pick 2021: Highlights in Cell Growth and Division
}

\author{
Philipp Kaldis * \\ Department of Clinical Sciences, Lund University, Clinical Research Centre (CRC), Malmö, Sweden
}

Keywords: cell biology, developmental biology, cell growth, cell division, metabolism, neural development

Editorial on the Research Topic

Editor's Pick 2021: Highlights in Cell Growth and Division

The section "Cell Growth and Division" of Frontiers in Cell and Developmental Biology was started 6 years ago with the aim to capture exciting research in the broadest possible term of cell and developmental biology. This section has come a long way and after publishing approximately 900 manuscript, it is well established.

For the year 2021, we decided to launch a "research topic" named "Editor's Pick 2021: Highlights in Cell Growth and Division" to highlight some of the exciting manuscript that were published. The goal was to capture and highlight some of the exciting manuscripts, which reflect this section's goals in the broadest sense. Therefore, you should not be surprised to find topics like neural (stem cell) differentiation (Ly and Wang; Yan et al.), spermatogenesis (Rahman and Pang; Zheng et al.), hair development (Fukuda et al.), neural development (Su et al.), genetic mouse engineering (Jang et al.), hearing loss (Zhong et al.; Yang et al.), cell cycle (Creff and Besson; Jang et al.; Ly and Wang), cytokinins (Gibb et al.), gastric cancer (Jiang et al.), cardiomyocyte regeneration (Bo et al.), and metabolism (Su et al.; Bo et al.). Although all these topics are exciting and are well reflected in our section, we seek manuscripts also in other emerging research fields that are connected to cell and developmental biology.

I would like to thank all the authors of the manuscripts of the research topic "Editor's Pick 2021:

Edited and reviewed by: Song-Tao Liu,

University of Toledo, United States

*Correspondence:

Philipp Kaldis

philipp.kaldis@med.lu.se

Specialty section:

This article was submitted to

Cell Growth and Division,

a section of the journal

Frontiers in Cell and Developmental

Biology

Received: 21 January 2022

Accepted: 03 February 2022

Published: 07 March 2022

Citation:

Kaldis P (2022) Editorial: Editor's Pick 2021: Highlights in Cell Growth and Division. Front. Cell Dev. Biol. 10:859568. doi: 10.3389/fcell.2022.859568
Highlights in Cell Growth and Division" for their contribution to science, to their research field, and to our section. At the same time, I should highlight the efforts of all the associate editors and review editors without whom we could not run a successful journal.

Since we have now started a new year, I am looking forward to a lot of exciting research and hope that some of it will be published in our section.

\section{AUTHOR CONTRIBUTIONS}

The author confirms being the sole contributor of this work and has approved it for publication.

Conflict of Interest: The author declares that the research was conducted in the absence of any commercial or financial relationships that could be construed as a potential conflict of interest.

Publisher's Note: All claims expressed in this article are solely those of the authors and do not necessarily represent those of their affiliated organizations, or those of the publisher, the editors and the reviewers. Any product that may be evaluated in this article, or claim that may be made by its manufacturer, is not guaranteed or endorsed by the publisher.

Copyright $\odot 2022$ Kaldis. This is an open-access article distributed under the terms of the Creative Commons Attribution License (CC BY). The use, distribution or reproduction in other forums is permitted, provided the original author(s) and the copyright owner(s) are credited and that the original publication in this journal is cited, in accordance with accepted academic practice. No use, distribution or reproduction is permitted which does not comply with these terms. 